\title{
Л.В. Бондаренко
}

\section{ОКИСНЮВАЛЬНИЙ ГОМЕОСТАЗ ТА РІВНІ АТЕРОГЕННОСТІ НА ЕТАПАХ ФОРМУВАННЯ І РОЗВИТКУ ХРОНІЧНОГО ОБСТРУКТИВНОГО ЗАХВОРЮВАННЯ ЛЕГЕНІВ}

Харківська медична академія післядипломної освіти МОЗ України

Резюме. Доведено, що на етапах формування та розвитку хронічного обструктивного захворювання легенів (ХОЗЛ) відбуваються достовірно значимі зміни окисновідновного метаболізму та ліпідного спектра плазми крові, які проявляються: при зворотній обструкції активацією, а при незворотній - пригніченням активності ферментативного ланцюга та, відповідно, накопиченням первинних і вторинних продуктів перекисно-

Вступ. Дослідження спільних метаболічних механізмів хронічного обструктивного захворювання легенів (ХОЗЛ) та кардіоваскулярного ризику (КВР) з використанням новітніх біохімічних та імунологічних методів, доведено активацію перекисного окиснення ліпідів (ПОЛ), пригнічення антиоксидантної системи (АОС) хворих [2-4, 17-21].

Зокрема, це стосується іiі ферментативної та неферментативної ланок: супероксиддисмутази (СОД), каталази (Кат), глутатіонпероксидази (ГПР), $\alpha$-токоферолу ( $\alpha$-ТФА), цистеїну, глутатіону, карназину на тлі закономірних змін процесів вільнорадикального окиснення (ВРО) та деяких інших порушень метаболізму $[1,5-8,13]$. Водночас, за даними World Health Report, 3 третиною смертей від серцево-судинних подій асоційовані 10 основних факторів ризику (ФР), з яких на високий рівень холестерину припадає 4,4 млн випадків, тютюнопаління - 4,9 млн, артеріальну гіпертензію - 7,1 млн. При індексі маси тіла (IMT) у межах $25-28,9$ кг/м² кардіоваскулярний ризик

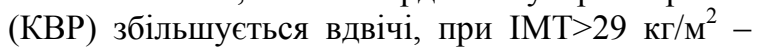
утричі $[10,14,20]$.

Проблему оцінки та корекції ліпідного профілю при ХОЗЛ не можна вважати вирішеною, оскільки поєднання високого КВР і ХОЗЛ потребує індивідуалізації лікувальної тактики і удосконалення існуючих клінічних протоколів [9, 11, $12,15,16]$. Окрім того, класичні версії шкал «SCORE» не враховують рівні холестерину ліпопротеїдів високої щільності (ХС-ЛПВЩ), глюкози, надлишкову вагу, абдомінальне ожиріння [10, 20]. Епідеміологічні дослідження показали, що порушення спектра ліпідів плазми крові, з підвищенням рівнів холестерину ліпопротеїдів низької щільності (ХС-ЛНЩ) і ТГ (холестерину ліпопротеїдів дуже низької щільності (ХС-ЛДНЩ)) і зниженням ХС-ЛВЩ - дисліпідемії або дисліпопротеїдемії, входять до числа трьох найбільш потужних факторів КВР.

Мета дослідження. Вивчити особливості окиснювального гомеостазу (ферментативний ланцюг, первинні і вторинні продукти окиснення) го окиснення ліпідів мембран клітин з одночасним зростанням атерогенності ліпідного профілю; гіпертригліцеридемія достовірно частіше реєструється при незворотній обструкції, ніж при зворотній.

Ключові слова: хронічне обструктивне захворювання легенів, кардіоваскулярний ризик, окиснювальний гомеостаз, ліпіди.

та рівнів атерогенності на етапах формування $\mathrm{i}$ розвитку хронічного обструктивного захворювання легенів.

Матеріал і методи. Первинною клінікоінформаційною базою для виконання дослідження стали результати комплексного обстеження 120 пацієнтів із обструктивним синдромом (62зі зворотною обструкцією та 58 - 3 незворотною: хворі на ХОЗЛ) віком $(38 \div 60$ р.) і 30 пацієнтів групи контролю. Для оцінки функції зовнішнього дихання (ФЗД) аналізували динаміку об'єму форсованого видоху за першу секунду $\left(\mathrm{OФB}_{1}, \mathrm{FEVI}-\right.$ forced expiratory flow in $1 \mathrm{sec})$, форсовану життеву ємкість легенів (ФЖЄЛ), співвідношення

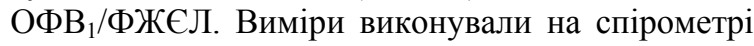
MS-22 (Microprocessor spirometer Controlled, Угорщина); визначали наступні швидкісні показники: ОФВ 1 - об'єм повітря, що видихається за першу секунду при максимально швидкому видиху; у відсотках до ФЖЄЛ. Розраховували спеціальний індекс: ОФВ $/$ ФЖЕЛ $\left(\mathrm{FEV}_{1} / \mathrm{FVC}=\mathrm{Index}\right.$ Gaenslar); $\mathrm{MOC}_{25}$ - максимальна об'ємна швидкість видоху на рівні $25 \%$ ФЖЕЛ, аналогічно $\mathrm{MOC}_{50}$ i MOC $_{75}$. Дослідження виконано за стандартизованою програмою збирання, накопичення та аналізу результатів. Окрім загальноклінічних методів, виконано дослідження стану окисновідносних процесів (ОВП) на рівні трьох базових підсистем: окисної модифікації білків та нуклеїнових кислот, біоенергетики клітин, ферментативного ланцюга та перекисного окиснення ліпідів (ПОЛ) мембран клітин і NO-залежних метаболітів. Стан ферментативного ланцюга АОЗ оцінювали за показниками вмісту супероксиддисмутази (СОД), глутатіонпероксидази (ГПР), каталази (КАТ) в еритроцитах та $\alpha$-токоферолу ацетату ( $\alpha$ ТФА) у сироватці крові хворих. Активність СОД визначалася неферментативним методом, який заснований на здатності СОД інгібувати відновлення нітросинього тетразолю за наявності NAD$\mathrm{H}_{2}$ та феназинметасульфату. Активність ГПР визначали за методом R. Olinescu; принцип методу заснований на виявленні витраченого глутатіону, сульфгідрильні групи якого в поєднанні з реакти- 
вом Елманса дають забарвлення у жовтий колір; визначається із застосуванням спектрофотометра при $\lambda=412$ нм. Активність каталази визначався спектрофотометрично при $\lambda=410$ нм; принцип методу базується на тому, що каталаза в аналізованому об'ємі реагує із перекисом водню, залишковий вміст якого визначався в реакції з молібдатом амонію. Активність ферменту оцінювали за ступенем хімічного розпаду перекису водню, колорометрично. Визначення $\alpha$-ТФА виконано спектрофотометрично при $\lambda=540$ нм; принцип методу базується на тому, що $\alpha-$ ТКФ відновлює $\mathrm{Fe}^{3+}$ у $\mathrm{Fe}^{2+}$ в еквівалентному співвідношенні, при цьому новоутворений $\mathrm{Fe}^{2+}$ формує забарвлений комплекс $3 \alpha, \alpha^{\prime}$-дипіридилом, максимум поглинання якого знаходиться при $\lambda=540$ нм. Вміст малонового альдегіду (МА), як індикатора ВРО в плазмі, визначено за методом Стальної І.Д. та Гаришвілі М.С.; принцип методу базується на здатності МА реагувати з 2-тіобатуровою кислотою (ТБК), утворюючи забарвлений триметиловий комплекс із максимумом поглинання при $\lambda=532$ нм; оптичну щільність вимірювали на спектрофотометрі “Specol-10”. Вміст дієнових кон'югат (ДК) у плазмі; принцип методу полягає в екстрагуванні ДК сумішшю гептану та ізопропілового спирту і визначення їх вмісту в гептановій фазі (суміш сироватки крові з гептаном гомогенізували у пристрої Поттера-Елвегейма). Після розшарування фаз відбирали гептанову фракцію та визначали оптичну щільність на спектрофотометрі «Perkin Elmelzambda - 20» при $\lambda=232$ нм; вміст ТК у плазмі виконували аналогічно ДК, але як фонову пробу використано гептан, а рівень ТК визначався при $1=270$ з перерахунком у мкмоль/л плазми. Вміст NO-залежних метаболітів $\left(\mathrm{NO}_{\mathrm{MET}}\right)$ у плазмі визначено за методикою Грисса, якою передбачається послідовність підготовки плазми 3 наступною інкубацією суміші плазми та реактиву Грисса і спектрофотометрію надопадової рідини при $l=540$ нм проти стандартизованих розведень реактиву; результат перераховували у мкмоль/л плазми.

У сироватці крові визначали рівні вмісту загального холестерину (ЗЛ), тригліцеридів (ТГ) та ліпопротеїнів високої (ЛПВЩ), низької (ЛПНЩ) та дуже низької (ЛПДНЩ) щільності колориметрично. Виходячи із рекомендацій експертів ВООЗ для ліпідних лабораторій, 3Х плазми визначали багатоетапним методом у модифікації L.L.Abel $з$ подальшим розрахунком ЛПВЩ та ЛПНШ.

При виконанні дослідження застосовано методи варіаційної статистики 3 первинним аналізом імовірнісного розподілу ознак, розрахунком середніх значень показників (М), їх середніх похибок $( \pm \mathrm{m})$ з оцінкою достовірності результатів 3 використанням критерію Стьюдента (t).

Результати дослідження та їх обговорення. Аналіз про- та антиоксидантного захисту серед пацієнтів різних респіраторних груп базувався на показниках активності супероксиддисмутази (СОД), каталази (КАТ), глутатіонпероксидази (ГПР) та вмісту $\alpha$-ТФА, а також по накопиченню первинних та вторинних продуктів ПОЛ мембран клітин і NO-залежних метаболітів (табл.1).

Виявлено, що ферментативна активність СОД у групі 120 пацієнтів із бронхообструктив-

Таблиця 1

Показники стану про- та антиоксидантного захисту хворих: перекисне окиснення ліпідів

\begin{tabular}{|c|c|c|c|c|c|}
\hline \multirow{2}{*}{\multicolumn{2}{|c|}{$\begin{array}{c}\text { Індикатори } \\
\text { функціонального стану ферментативного } \\
\text { ланцюга про- та антиоксидантного захисту }\end{array}$}} & \multicolumn{4}{|c|}{ Групи пацієнтів } \\
\hline & & \multirow{2}{*}{$\begin{array}{c}\text { Контрольна } \\
\left(\mathrm{n}_{0}=30\right) \\
154,06 \pm 3,61\end{array}$} & \multirow{2}{*}{$\begin{array}{c}\begin{array}{c}\text { з обструктив- } \\
\text { ним синдро- } \\
\text { мом }\left(\mathrm{n}_{1}=120\right) \\
159,17 \pm 0,71^{\text {a }}\end{array}\end{array}$} & \multirow{2}{*}{$\begin{array}{c}\begin{array}{c}\text { зі зворотною } \\
\text { обструкцією } \\
\left({ }^{0} n_{1}=62\right)\end{array} \\
160,34 \pm 1,12^{\text {a }}\end{array}$} & \multirow{2}{*}{$\begin{array}{c}\begin{array}{c}3 \text { незворотною } \\
\text { обструкцією } \\
\left({ }^{1} n_{1}=58\right)\end{array} \\
157,91 \pm 0,84^{\sigma}\end{array}$} \\
\hline \multirow{4}{*}{$\begin{array}{c}\text { Фермента- } \\
\text { тивний } \\
\text { ланцюг } \\
\text { антиокси- } \\
\text { дантного } \\
\text { захисту }\end{array}$} & $\begin{array}{c}\text { Активність супероксиддис- } \\
\text { мутази, у.о./хв }\end{array}$ & & & & \\
\hline & $\begin{array}{c}\text { Активність каталази, } \\
\text { у.о./хв }\end{array}$ & $6,41 \pm 0,07$ & $6,13 \pm 0,04^{\mathrm{a}}$ & $6,13 \pm 0,06^{\mathrm{a}}$ & $6,13 \pm 0,03^{\mathrm{a}}$ \\
\hline & $\begin{array}{c}\text { Активність глутатіонперок- } \\
\text { сидази, у.о./хв }\end{array}$ & $33,34 \pm 0,22$ & $32,04 \pm 0,18^{\mathrm{a}}$ & $31,52 \pm 0,30^{\mathrm{a}}$ & $32,60 \pm 0,16^{\mathrm{a}, \bar{\sigma}}$ \\
\hline & $\begin{array}{l}\text { Вміст } \alpha \text {-ТФА, } \\
\text { мкмоль/л }\end{array}$ & $1,05 \pm 0,01$ & $1,06 \pm 0,01$ & $1,06 \pm 0,01$ & $1,06 \pm 0,01$ \\
\hline \multirow{4}{*}{$\begin{array}{l}\text { Стан окис- } \\
\text { нення фос- } \\
\text { фоліпідів та } \\
\text { NO- мета- } \\
\text { болітів }\end{array}$} & $\begin{array}{c}\text { Вміст дієнових кон'югат, } \\
\text { мкмоль/л }\end{array}$ & $0,49 \pm 0,02$ & $0,51 \pm 0,01$ & $0,54 \pm 0,01^{\mathrm{a}}$ & $0,50 \pm 0,01^{\sigma}$ \\
\hline & $\begin{array}{c}\text { Вміст малонового альдегі- } \\
\text { ду, мкмоль/л }\end{array}$ & $0,81 \pm 0,01$ & $0,82 \pm 0,01$ & $0,81 \pm 0,01$ & $0,82 \pm 0,01$ \\
\hline & $\begin{array}{l}\text { Вміст триєнкетонів, } \\
\text { мкмоль/л }\end{array}$ & $0,34 \pm 0,01$ & $0,32 \pm 0,01$ & $0,33 \pm 0,02$ & $0,32 \pm 0,01$ \\
\hline & $\begin{array}{l}\text { Вміст нітританіону, } \\
\text { мкмоль/л }\end{array}$ & $31,02 \pm 0,19$ & $31,54 \pm 0,20^{\mathrm{a}}$ & $31,64 \pm 0,30^{\mathrm{a}}$ & $32,44 \pm 0,27^{\mathrm{a}, \sigma}$ \\
\hline
\end{tabular}

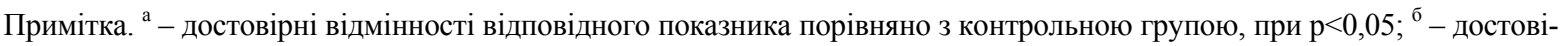
рні відмінності відповідного показника залежно від зворотності обструкції, при р <0,05 
Частота рівнів атерогенності у різних респіраторних групах обстежених

\begin{tabular}{|c|c|c|c|c|c|c|c|c|}
\hline \multirow{3}{*}{$\begin{array}{c}\text { Показники ліпідного } \\
\text { профілю: коефіцієнт } \\
\text { атерогенності }\end{array}$} & \multicolumn{8}{|c|}{ Респіраторні групи пацієнтів } \\
\hline & \multicolumn{2}{|c|}{$\begin{array}{c}\text { Контрольна група } \\
\left(\mathrm{n}_{0}=30\right)\end{array}$} & \multicolumn{2}{|c|}{$\begin{array}{c}\text { Пацієнти з обструк- } \\
\text { тивним синдромом } \\
\left(\mathrm{n}_{1}=120\right)\end{array}$} & \multicolumn{2}{|c|}{$\begin{array}{c}\text { Пацієнти зі зворот- } \\
\text { ною обструкцією } \\
\left({ }^{0} n_{1}=62\right)\end{array}$} & \multicolumn{2}{|c|}{$\begin{array}{c}\text { Пацієнти з незворо- } \\
\text { тною обструкцією } \\
\left({ }^{1} n_{1}=58\right)\end{array}$} \\
\hline & осіб & $\mathrm{M} \pm \mathrm{m}, \%$ & осіб & $\mathrm{M} \pm \mathrm{m}, \%$ & осіб & $\mathrm{M} \pm \mathrm{m}, \%$ & осіб & $\mathrm{M} \pm \mathrm{m}, \%$ \\
\hline$<2,5$ & 18 & $60,0 \pm 8,9$ & 12 & $10,0 \pm 2,7^{\mathrm{a}}$ & 10 & $16,1 \pm 4,7^{\mathrm{a}}$ & 2 & $3,4 \pm 2,4^{\mathrm{a}, \sigma}$ \\
\hline $2,5 \div 3,0$ & 5 & $16,7 \pm 6,8$ & 28 & $23,3 \pm 3,9$ & 16 & $25,8 \pm 5,6$ & 12 & $20,7 \pm 5,3$ \\
\hline $3,0 \div 3,5$ & 6 & $20,0 \pm 7,3$ & 32 & $26,7 \pm 4,0$ & 19 & $30,6 \pm 5,9$ & 13 & $22,4 \pm 5,5$ \\
\hline$>3,5$ & 1 & $3,3 \pm 3,3$ & 48 & $40,0 \pm 4,5^{\mathrm{a}}$ & 17 & $27,4 \pm 5,7^{\mathrm{a}}$ & 31 & $53,4 \pm 6,5^{\text {a, } 6}$ \\
\hline Разом & \multicolumn{2}{|c|}{$2,42 \pm 0,05$} & \multicolumn{2}{|c|}{$3,40 \pm 0,07$} & \multicolumn{2}{|c|}{$3,17 \pm 0,08$} & \multicolumn{2}{|c|}{$3,65 \pm 0,10$} \\
\hline
\end{tabular}

Примітка. ${ }^{\text {a }}$-порівняно $з$ контролем, ${ }^{6}$-порівняно між групами пацієнтів зі зворотною та незворотною обструкцією при $\mathrm{p}<0,05$

ним синдромом (БОС), у цілому була достовірно $(\mathrm{p}<0,05)$ вищою, ніж серед пацієнтів контрольної групи (відповідно $154,06 \pm 3,61 \quad$ у.о./хв та $159,17 \pm 0,71$ у.о./хв); при цьому, у разі зворотної обструкції ця активність зареєстрована достовірно вищою, ніж за наявності ХОЗЛ (відповідно $160,34 \pm 1,12$ у.о./хв та $157,91 \pm 0,84$ у.о./хв, p<0,01). Наведене свідчить на користь збереження високих рівнів ферментативної активності АОЗ, зокрема СОД, при зворотній обструкції та, водночас, про збереження ферментативної активності СОД у пацієнтів із ХОЗЛ (порівняно 3 контролем: $154,06 \pm 3,61$ у.о./Хв та $157,91 \pm 0,84$ y.o./хв, $>00,05$ ).

Ферментативна активність КАТ у групі 120 пацієнтів із БОС, у цілому була достовірно $(\mathrm{p}<0,05)$ нижчою, ніж серед пацієнтів контрольної групи (відповідно 6,13 $\pm 0,04$ у.о./хв та $6,41 \pm 0,07$ у.о./Хв); у разі зворотної обструкції та серед пацієнтів із ХОЗЛ ця активність зареєстрована практично на однаковому рівні (відповідно $6,13 \pm 0,06$ у.о./хв та $6,13 \pm 0,03$ у.о./хв, p>0,05). Наведе свідчить на користь високої клінічної інформативності зниження ферментативної активності AO3, зокрема КАТ, що відбувається вже на ранніх етапах формування БОС.

Активність ГПР у групі 120 пацієнтів із БОС, у цілому була достовірно $(\mathrm{p}<0,05)$ нижчою, ніж серед пацієнтів контрольної групи (відповідно $32,04 \pm 0,18$ у.о./хв та $33,34 \pm 0,22$ у.о./хв); при цьому, у разі зворотної обструкції ця активність зареєстрована достовірно нижчою, ніж за наявності

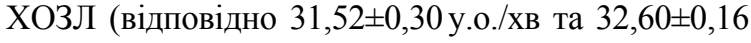
У.o./хв, $\mathrm{p}<0,05)$. Наведене може свідчити про компенсаторний характер зростання активності ГПР при ХОЗЛ порівняно з пацієнтами, які мають зворотний характер обструктивних порушень, однак не досягається рівня активності ГПР порівняно 3 контролем (відповідно $32,60 \pm 0,16$ у.о./хв та 33,34 $\pm 0,22$ у.о./хв).

Аналіз вмісту $\alpha$-ТФА, як екзогенного чинника формування активності ферментативного ланцюга АОЗ, виявив достатньо стабільні $(\mathrm{p}>0,05)$ його рівні в досліджуваних групах пацієнтів (у контролі - 1,05 $\pm 0,01$ мкмоль/л, при зворотній обструкції - 1,06 $\pm 0,01$ мкмоль/л, при ХОЗЛ $1,06 \pm 0,01$ мкмоль/л), що може свідчити про найбільший системоутворюючий вплив $\alpha$-ТФА на стан ферментативного ланцюга АОЗ.

Виявлено, що рівень вмісту такого первинного продукту окисної модифікації фосфоліпідів, як ДК у групі 120 пацієнтів із БОС, у цілому не відрізнявся від аналогічного показника пацієнтів контрольної групи (відповідно $0,51 \pm 0,01$ мкмоль/л та 0,49 $\pm 0,02$ мкмоль/л); при цьому, у разі зворотної обструкції вміст ДК достовірно вищий, ніж за наявності ХОЗЛ (відповідно

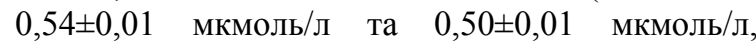
$\mathrm{p}<0,05)$. Зазначаємо, що рівень вмісту МА в порівнюваних групах пацієнтів коливався в межах від $0,81 \pm 0,01$ мкмоль/л (у групі контролю) до $0,82 \pm 0,01$ мкмоль/л (серед хворих на ХОЗЛ) та достовірно не відрізнявся. Наведене свідчить, що накопичення первинних продуктів ПОЛ на етапах розвитку ХОЗЛ є інформативним індикатором клініко-метаболічних розладів.

Дещо по-іншому характеризується процес накопичення вторинних продуктів ПОЛ серед пацієнтів порівнюваних груп, а саме: вміст ТК був стабільним (коливався у межах від до та достовірно не відрізнявся), тоді як вміст нітританіону характеризувався достовірними змінами. Так, у групі 120 пацієнтів із БОС, рівень вмісту нітританіону достовірно $(\mathrm{p}<0,05)$ відрізнявся від аналогічного показника пацієнтів контрольної групи (відповідно $31,54 \pm 0,20$ мкмоль/л та 31,64 $\pm 0,30$ мкмоль/л); при цьому, у разі зворотної обструкції вміст нітританіону був також достовірно нижчим, ніж за наявності ХОЗЛ (відповідно 32,44 $\pm 0,27$ мкмоль/л та $31,02 \pm 0,19$ мкмоль/л, $\mathrm{p}<0,05)$.

Аналіз рівня вмісту ЗХ виявив, що серед пацієнтів із незворотною обструкцією він становив $(5,6 \pm 0,1)$ ммоль/л та достовірно перевищував відповідний показник пацієнтів зі зворотною обструкцією - $(4,52 \pm 0,22)$ ммоль/л, $\mathrm{p} \leq 0,05$. Вивчен- 
ня рівня вмісту ТГ серед пацієнтів із обструктивним синдромом (ОС) виявило його коливання у межах $(1,89 \pm 0,17)$ ммоль/л та достовірно не відрізняючись за ознакою статі ( $\mathrm{p} \geq 0,05)$. Аналіз рівня вмісту ТГ у пацієнтів із незворотною обструкцією становив $(2,4 \pm 0,2)$ ммоль/л та достовірно перевищував відповідний показник осіб зі зворотною обструкцією - $(1,04 \pm 0,08)$ ммоль/л, $\mathrm{p} \leq 0,001$. Вміст у сироватці крові ЛПВЩ за наявності у хворих незворотної обструкції становив $(1,2 \pm 0,04)$ ммоль/л та достовірно відрізнявся залежно від статі пацієнтів: у жінок - $(1,3 \pm 0,05)$ ммоль/л, у чоловіків - $(1,1 \pm 0,06)$ ммоль/л. У цілому, вміст ЛПВЩ відповідав загальновизнаним рівням, однак достовірно нижчим був у пацієнтів iз незворотною обструкцією. Коефіцієнт атерогенності серед пацієнтів зі зворотною обструкці$\epsilon ю\left({ }^{0} n_{1}=62\right)$ становив $(3,17 \pm 0,08)$ од., тоді як у разі іiі незворотності $\left({ }^{1} n_{1}=58\right)$ він був достовірно вищим - $(3,65 \pm 0,10)$ од. та перевищував загальноприйнятий рівень.

Гіперхолестеринемія (відповідає типу IIA, за D.Fredrickson) діагностована серед $(34,5 \pm 3,7) \%$ пацієнтів із ОС достовірно частіше в осіб із незворотною обструкцією (відповідно 44,3 \% та $25,0 \%, \mathrm{p} \leq 0,05)$. Гіпертригліцеридемія (відповідає типу IV) діагностована серед $(47,4 \pm 5,1) \%$ осіб із незворотною обструкцією. У групах пацієнтів із ОС комбіновані типи дисліпідемії діагностовані 3 однаковою $(\mathrm{p} \geq 0,05)$ частотою: тип III $(26,3 \pm 4,5) \%$, а тип IIB - у $(16,8 \pm 3,8) \%$ хворих.

\section{Висновки}

1. Узагальнюючи виявлені нами клінікометаболічні ефекти зазначаємо, що на етапах формування та розвитку бронхообструктивного синдрому, на рівні ферментативного ланцюга антиоксидантного захисту формується особливий метаболічний профіль, який характеризується:

- у разі зворотної обструкції: зростання активності ферментативного ланцюга, зокрема рівня вмісту супероксиддисмутази $(\mathrm{p}<0,05)$ при одночасному зниженні $(\mathrm{p}<0,05)$ рівня активності каталази та глутатіонпероксидази при стабільному рівні вмісту $\alpha$-ТФА порівняно з пацієнтами групи контролю. Також, у пацієнтів зі зворотною обструкцією, на цьому етапі формування патології, виявлено активне накопичення первинних (зокрема - дієнових кон'югат) та вторинних (нітританіону) продуктів перекисного окиснення;

- у разі незворотної обструкції: пригнічення активності ферментативного ланцюга, зокрема зменшення рівня вмісту супероксиддисмутази $(\mathrm{p}<0,05)$ при одночасному зниженні $(\mathrm{p}<0,05)$ рівня активності каталази та глутатіонпероксидази при стабільному рівні вмісту $\alpha$ - токоферолу ацетату порівняно $з$ пацієнтами, які мають зворотну обструкцію та пацієнтів групи контролю на тлі відсутності накопичення первинних продуктів та більш активного, ніж при зворотній обструкції, накопичення вторинних (нітританіон) продуктів перекисного окиснення;
- вміст ліпопротеїдів високої щільності відповідає референтним рівням, однак у пацієнтів із незворотною обструкцією він $є$ достовірно нижчим $(\mathrm{p}<0,01)$. Гіпертригліцеридемія достовірно частіше реєструється при незворотній обструкції, ніж при зворотній $(\mathrm{p}<0,05)$. У пацієнтів із обструктивним синдромом має місце достовірне зростання рівня ліпопротеїдів дуже низкої щільності: цей рівень перевищує референтні значення практично у два рази. Коефіцієнт атерогенності в пацієнтів із бронхообструктивним синдромом сягає $3,40 \pm 0,07$ од. та достовірно перевищує референтні рівні. Високий рівень атерогенності ліпідного профілю виявлено серед $27,4 \pm 5,7$ \% осіб зі зворотною обструкцією та $53,4 \pm 6,5 \%$ хворих на хронічне обструктивне захворювання легенів.

Перспективи подальших досліджень у цьому напрямку пов'язані з розробкою алгоритмів індивідуалізації амбулаторно-поліклінічного супроводу пацієнтів з різним рівнем КВР на етапах формування та розвитку ХОЗЛ.

Дослідження виконано у межах НДР кафедри сімейної медицини, народної і нетрадиційної медицини та санології (завкафедри проф. С.П.Шкляр) Харківської медичної академії післядипломної освіти МО3 України (ректор, проф. О.М. Хвисюк) «Розробка, апробація та впровадження доказових технологій оцінки клінічної ефективності комплексної терапії із застосуванням альтернативних методів традиційної медицини», держреєстрація № 0108 U 005248.

\section{Література}

1. Белозёрова С.В. Кластерный подход к выявлению и коррекции факторов риска сердечно-сосудистых заболеваний / С.В. Белозёрова, С.В. Богун // Укр. терапевт. ж. - 2010. - №1. - С. 105-110.

2. Березин А.Е. Хроническая обструктивная болезнь легких и кардиоваскулярный риск / А.Е. Березин // Укр. мед. часопис. - 2009. - № 2 (70). - С. 62-68.

3. Бицадзе Р.М. Метаболические особенности сердечнососудистой патологии / Р.М. Бицадзе, В.В. Дорофейков, А.Г. Обрезан / Вестн. С-Пб ун-та. - 2009. - № 1. C. 28-33.

4. Бондаренко Л.В. Биомаркеры системного воспаления у пациентов с хроническим обструктивным заболеванием лёгких / Л.В. Бондаренко // Зб. матеріалів міжнар. наук.-практ. конференції [«Пріоритетні напрямки у медицині: від теорії до практики»] (Одеса, 18-19.09.2015p.). - Одеса: Південна фундація медицини, 2015. - С. 28-33.

5. Бондаренко Л.В. Кардіоваскулярний ризик та хронічне обструктивне захворювання легенів: ліпідний профіль і рівні атерогенності в респіраторних групах пацієнтів / Л.В. Бондаренко: матеріали Міжнар. наук.практ. конференції [«Фундаментальні науки - практичній медицині: морфофункціональні методи дослідження онтогенетичних перетворень, фізіологічних та метаболічних процесів»] (30.09-01.10.2015p., ІваноФранківськ). - Івано-Франківський державний медичний університет, 2015. - С. 17-20.

6. Бондаренко Л.В. Кардіоваскулярний ризик та хронічне обструктивне захворювання легенів: клінікоанамнестичний аналіз деяких спільних факторів / Л.В. Бондаренко: матеріали VIII Науково-практичної конференції [«Актуальні питання патології за умов дії надзвичайних факторів на організм». - ДВНЗ «Тернопільський державний медичний університет 
імені І.Я. Горбачевського» (01-02.2015p.). - Тернопіль, 2015. - С. 12-13.

7. Бондаренко Л.В. Оценка взаимосвязи между дополнительным кардиоваскулярным риском и тяжестью хронического обструктивного заболевания лёгких / Л.В. Бондаренко: матеріали Міжнар. наук.-практ. конференції [«Медичні науки: історія розвитку, сучасний стан та перспективи досліджень»] (25-26.09.2015p.). Львів: Львівська медична спільнота, 2015. - С. 10-13.

8. Вікові та соматичні особливості перебігу хронічного обструктивного захворювання легень за умов поєднаного ураження серцево-судинної системи / O.I. Волошин, Н.М. Малкович, Г.Я. Ступницька [та ін.] // Бук. мед. вісник. - 2009. - Т. 13, № 3. - С. 20-25.

9. Климанов И.А. Механизмы формирования и маркеры оксидативного стресса при патологиях респираторного тракта / И.А. Климанова, С.К. Соодаева // Пульмонология. -2009 . - № 2. - С. 113.

10. Коморбідність і високий кардіоваскулярний ризик ключові питання сучасної медицини / Г.Д. Фадєєнко, О.Є. Гріднєв, А.О. Несен [та ін.] // Укр. терапевт. ж. 2013. - № 1. - C. 102-107.

11. Ласиця Т.С. Особливості надання первинної медичної допомоги пацієнтам з важким перебігом хронічного обструктивного захворювання легень і коморбідною артеріальною гіпертензією / Т.С. Ласиця // Експерим. та клін. фізіол. і біохімія. - 2013. - № 2. - С. 81.

12. Несен А.О. Хронічні неінфекційні захворювання: акцент на коморбідність і підвищений кардіоваскулярний ризик / А.О. Несен // Укр.терапевт. ж. - 2014. № 2. - C. 26-32.
13. Нетюхайло Л.Г. Активні форми кисню (огляд літератури) / Л.Г. Нетюхайло, С.В. Харченко // Young Scientist. - 2014. - № 9 (12). - С. 131-135.

14. Островський М.М. Бронхообструкційний синдром: актуальні питання діагностики та лікування / М.М. Островський // Укр. пульмонол. ж. - 2011. № 2. - С. 14-16.

15. Фещенко Ю.И. Новая редакция глобальной инициативы по ХОЗЛ / Ю.И. Фещенко // Укр. пульмонол. ж. 2012. - № 2. - С. 6-8.

16. Ячник А.И. Донатор оксида азота в терапии больных ХОЗЛ / А.И. Ячник // Укр. пульмонол. ж. - 2012. № 2. - C. 33-34.

17. Birben E. Oxidative stress and antioxidant defense / E. Birben, U.M. Sahiner, C. Sackesen // WAO J. - 2012. Vol. 5. - P. 9-19.

18. Fanelli C. Linking oxidative stress, the renin-angiotensin system, and hypertension / C. Fanelli, R. Zatz // Hypertension. - 2011. - Vol. 57. - P. 373-374.

19. Kawut S.M. COPD: CardioPulmonary disease? / S.M. Kawut // Eur. Respir. J. - 2013. - № 41. P. 1241-1243.

20. Mullerova H. Cardiovascular comorbidity in chronic obstructive pulmonary disease: systematic literature review / H. Mullerova, A. Agusti, S. Erqou // Chest. - 2013. № 144. - P. 1163-1178.

21. Rahman I. Antioxidant pharmacological therapies for COPD / I. Rahman, W. Mac Nee // Current Opinion in Pharmacology. - 2012. - Vol. 12. - P. 256-265.

\section{ОКИСЛИТЕЛЬНЫЙ ГОМЕОСТАЗ И УРОВЕНЬ АТЕРОГЕННОСТИ НА ЭТАПАХ ФОРМИРОВАНИЯ И РАЗВИТИЯ ХРОНИЧЕСКОГО ОБСТРУКТИВНОГО ЗАБОЛЕВАНИЯ ЛЁГКИХ}

\section{Л.В. Бондаренко}

Резюме. Доказано, что на этапах формирования и развития хронического обструктивного заболевания лёгких (ХОЗЛ) происходят достоверно значимые изменения окислительно-восстановительного метаболизма и липидного спектра плазмы крови, которые проявляются: при обратимой обструкции активацией, а при необратимой - угнетением активности ферментативной цепи и, соответственно, накоплением первичных и вторичных продуктов перикисного окисления липидов мембран с одновременным увеличением атерогенности липидного профиля, гипертриглицеридемия достоверно чаще регистрируется при необратимой обструкции, чем при обратимой.

Ключевые слова: хроническое обструктивное заболевание лёгких, кардиоваскулярный риск, окислительный гомеостаз, липиды.

\section{OXIDATIVE HOMEOSTASIS AND ATHEROGENIC LEVELS AT THE STAGE OF CHRONIC OBSTRUCTIVE PULMONARY DISEASE}

\section{L.V. Bondarenko}

Abstract. It is proved that at the stages of formation and development of chronic obstructive pulmonary disease (COPD) we observe fairly significant changes of oxidative reductive metabolism and lipid spectrum of blood plasma, that manifest themselves: at the reversible obstruction - by activation, while at the irreversible one - by inhibition of enzymatic chain and, consequently, by the accumulation of primary and secondary peroxidation products of lipid of cells membranes with a simultaneous increase of atherogenic lipid profile; hypertriglyceridemia is significantly more often registered at the case of irreversible obstruction than at the reverse one.

Key words: chronic obstructive pulmonary disease, cardiovascular risk, oxidative homeostasis, lipids.

Kharkiv Medical Academy of Postgraduate Education of MHC of Ukraine

Рецензент - проф. О.І. Волошин

Buk. Med. Herald. - 2015. - Vol. 19, № 4 (76). - P. $22-26$

Надійшла до редакції 16.10.2015 року

(с) Л.В. Бондаренко, 2015 